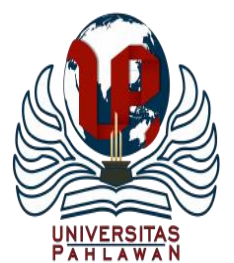

Edukatif : Jurnal Ilmu Pendidikan Volume 3 Nomor 4 Tahun 2021 Halm 2027 - 2036

EDUKATIF: JURNAL ILMU PENDIDIKAN

Research \& Learning in Education

https://edukatif.org/index.php/edukatif/index

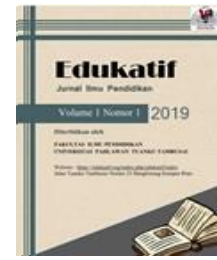

\title{
Implementasi Kebijakan Pembelajaran Tatap Muka di Pesantren Taruna Al Qur'an Putri Yogyakarta Masa Darurat Covid-19
}

\author{
Rafi’ul Akmal Athaillah ${ }^{1 凶}$, Fatimah Nur Rahma ${ }^{2}$, M. Syahrul Qhodi Alam³, Burhanudin \\ Ahmad Fauzi ${ }^{4}$, Fransisca Wulandari ${ }^{5}$, Imam Safii ${ }^{6}$ \\ Universitas Ahmad Dahlan, Indonesia ${ }^{1,2,3,4,5,6}$ \\ E-mail : rafiul1900031004@webmail.uad.ac.id ${ }^{1}$, fatimah1900031012@ webmail.uad.ac.id ${ }^{2}$, \\ m1900031028@webmail.uad.ac.id ${ }^{3}$, burhanudin1900031033@webmail.uad.ac.id ${ }^{4}$, \\ fransisca1900031034@webmail.uad.ac.id ${ }^{5},{\underline{\text { safii14442@ } \text { gmail.com }^{6}}}^{6}$
}

\begin{abstract}
Abstrak
Satu tahun lebih pandemi covid-19 melanda dunia dan berimbas pada dunia pendidikan termasuk pondok pesantren. Kebijakan terkait pembelajaran di masa pandemi covid-19 yang dibuat oleh pemerintah melatarbelakangi Pondok Pesantren Taruna Al-Qur'an putri dalam pengambilan kebijakan pendidikan di pondok pesantren.Tujuan penelitian ini untuk mengetahui kebijakan-kebijakan pendidikan pada pembelajaran tatap muka di Pondok Pesantren Taruna Al-Qur'an Putri selama pandemic covid-19. Metode penelitian yang penulis gunakan penelitian kualitatif bersifat deskriptif. Peneliti mendeskripsikan suatu obyek, fenomena, atau setting sosial yang akan dilaporkan dalam tulisan yang bersifat naratif. Teknik pengumpulan data dilakukan dengan dengan menggunakan triangulasi teknik yaitu pengungkapan data dilakukan kepada sumber data.Teknik ini dilakukan dengan menggabungkan teknik wawancara, dan observasi. Hasil penelitian menunjukkan bahwa Pondok Pesantren Taruna Al-Qur'an Putri telah menerapkan protokol kesehatan yang mengacu pada kebijakan pemerintahan tentang ketentuan dan panduan penyelenggaran pembelajaran tatap muka di pondok pesantren.
\end{abstract}

Kata Kunci: Kebijakan Pendidikan, Pondok Pesantren Taruna Qur’an, Covid-19.

\section{Abstract}

One more year of pandemic covid-19 hit the world and impacted on the worl of education including boarding schools. Policies related to learning during the covid-19 pandemic made by the government behind Pondok Pesantren Taruna Al-Qur'an Putri in education policy making in boarding schools. The purpose of this study is to describe the government's policy in organizing education in Pondok Pesantren Taruna Al-Qur'an Putri during the covid-19 pandemic. The research method that the authors use qualitative research is descriptive. Researchers describe an object, phenomenon, or social setting that will be reported in narrative writing. Data colletion techniques are carried out using triangulation techniques that are data disclosures made to data soureces. This technique is done by combining interview, and observation. The results showed that Pondok Pesantren Taruna Al-qur'an Putri has impemented health protocols that refer to government policies on the provisions and guidelines for organizing face-to-face learning in boarding schools.

Keywords: Education Policy, Pondok Pesantren Taruna Al-Qur'an, Covid-19

Copyright (c) 2021 Rafi'ul Akmal Athaillah, Fatimah Nur Rahma, M. Syahrul Qhodi Alam, Burhanudin Ahmad Fauzi, Fransisca Wulandari, Imam Safii

$\triangle$ Corresponding author

Email : rafiul1900031004@webmail.uad.ac.id

DOI : https://doi.org/10.31004/edukatif.v3i4.1112

ISSN 2656-8063 (Media Cetak)

ISSN 2656-8071 (Media Online) 
2028 Implementasi Kebijakan Pembelajaran Tatap Muka di Pesantren Taruna Al Qur'an Putri Yogyakarta Masa Darurat Covid-19-Rafi'ul Akmal Athaillah, Fatimah Nur Rahma, M. Syahrul Qhodi Alam, Burhanudin Ahmad Fauzi, Fransisca Wulandari, Imam Safii

DOI: https://doi.org/10.31004/edukatif.v3i4.1112

\section{PENDAHULUAN}

Sudah satu tahun lebih, dunia dilanda pandemi covid-19 yang saat ini belum ada yang bisa mengehentikan penyebaran covid-19. Covid-19 merupakan pandemi kelima setelah pendemi flu tahun 1918. Hanya dalam hitungan bulan virus covid-19 mengakibatkan krisis di penjuru dunia termasuk di Indonesia. Sejarah munculnya coronavirus bermula pada 1 Desember 2019 terdapat laporan bahwa ada sekelompok manusia dengan kasus pneumonia di Kota Wuhan. Pada 12 Januari 2020, Organisasi Kesehatan dunia (WHO) untuk sementara menjuluki virus baru tersebut dengan julukan novel coronavirus (2019-nCoV). Dan pada tanggal 12 Februari 2020 WHO secara resmi mengubahnya menjadi coronavirus 2019 (COVID-19), dan menyatakannya sebagai pandemi dunia (Aidah, 2020).

Coronavirus berasal dari kata latin corona yang artinya "ruang kosong" atau "mahkota". Yang merupakan ciri dari partikel-partikel virus corona. Manusia yang terjangkit virus corona memiliki beberapa gejala diantara batuk, demam, pernapasan pendek, dan yang paling berbahaya virus ini dapat menyebabkan kematian (Wasito; Wuryastuti, 2020). Seseorang dapat terpapar virus covid-19 melalui droplet (tetesan kecil) dari mulut atau hidung ketika orang yang sudah terpapar bersin atau batuk, dan droplet tersebut tanpa disadari mengenai benda disekitarnya. Kemudian jika orang lain tanpa disadari menyentuh droplet tersebut lalu menyentuh mulut, hidung, dan mata maka orang tersebut dapat terinveksi Covid-19 bisa dengan gejala covid19 maupun tanpa gejala (Kemenskes, n.d.).

Dikarenakan Virus tersebut sangat mudah dan cepat menyebar dari orang keorang dan berdampak besar kepada masyarakat, pandemi covid-19 berhasil melumpuhkan berbagai sektor kehidupan bermasyarakat, pada akhirnya munculah kebijakan sosial seperti penguncian kota dan penutupan sekolah. Presiden Joko Widodo mengimbau segala aktivitas dilakukan didalam rumah seperti kerja dari rumah (KDR) Dan juga belajar dari rumah (BDR) Sejak 15 Maret 2020. Disektor pendidikan dampak pandemi ini adalah diberlakukannya lockdown dan penutupan secara paksa lembaga pendidikan, sekolah, dan perguruan tinggi. Penutupan berbagai lembaga pendidikan membuat proses kegiatan belajar mengajar dilakukan dengan daring atau dikenal pula dengan pembelajaran jarak jauh dengan memanfaatkan kecanggihan teknologi. Tidak terkecuali lembaga pendidikan non formal, yakni pondok pesantren.

Pada umumnya pembelajaran di pondok pesantren dilakukan secara tatap muka. Pondok pesantren merupakan lembaga pendidikan yang memiliki asrama, sehingga santriwan santriwati tidak terlepas dari aktivitas kehidupan di pondok pesantren selama 24 jam dari bangun tidur hingga tidur kembali (Rosyid, Moh Zaiful; Fauzi, Achmad; Mustajab; Subakti, 2020). Pondok pesantren pernah menjadi satu-satunya institusi pendidikan milik masyarakat pribumi yang memberikan konstribusi sangat besar dalam membentuk masyarakat melek huruf (literacy) dan melek budaya. Selain itu pondok pesantren tela memberikan dua macam konstribusi bagi sistem pendidikan di Indonesia. Pertama, adalah melestarikan dan malanjutkan sistem pendidikan rakyat, dan kedua yaitu mengubah sistem pendidikan aristokratis menjadi sistem pendidikan demokratis(Qomar, 2005). Pondok Pesantren memiliki kapasitas santri yang cukup banyak, sehingga dimasa pandemi pemerintah maupun masyarakat mengkhawatirkan jika terjadi klaster baru Covid-19 di pondok pesantren. Berbagai imbauan kebijakan pemerintah terkait pembelajaran masa pandemi turut dijalankan oleh lembaga pesantren sejak Maret 2020.

Kebijakan seringkali diterjemahkan dengan politik, aturan, program, keputusan, undangundang,peraturan, ketentuan, kesepakatan, konvensi, dan rencana strategis. Kebijakan yaitu aturan tertulis yanng merupakan keputusan formal organisasi ang bersifat mengikat, yang mengatur perilaku orang dengan tujuan untuk menciptakan tata nilai baru dalam masyarakat. Kebijakan akan menjadi rujukan utama para anggota organisasi atau anggota masyarakat dalam berperilaku(Teoretis, n.d.). Adapun kebijakan pemerinta terkait pembelajaran tatap muka di masa pandemi termasuk kebijakan pendidikan. Kebijakan pendidikan 
2029 Implementasi Kebijakan Pembelajaran Tatap Muka di Pesantren Taruna Al Qur'an Putri Yogyakarta Masa Darurat Covid-19-Rafi'ul Akmal Athaillah, Fatimah Nur Rahma, M. Syahrul Qhodi Alam, Burhanudin Ahmad Fauzi, Fransisca Wulandari, Imam Safii

DOI: https://doi.org/10.31004/edukatif.v3i4.1112

merupakan rumusan keputusan yang diambil terkait dengan kegiatan pendidikan, baik yang menyangkut metode pembelajaran, kurikulum, sarana prasarana pendidikan dan strategi pembelajaran yang harus diterapkan di kelas maupun di luar kelas agar dapat mencapai tujuan pendidikan (Winata et al., 2021).

Menteri Pendidikan dan Kebudayan (Mendikbud) Nadiem Anwar Makarim menyampaikan " Prioritas utama pemerintah adalah untuk mengutaakan kesehatan dan keselamatan peserta didik, pendidik, tenaga kependidikan, keluarga, dan masyarakat secara umum, serta mempertimbangkan tumbuh kembang peserta didik dan kondisi psikososial dalam upaya pemenuhan layanan pendidikan selama pandemi COVID19"(Pengelola web kemendikbud, 2020).

Pada awal-awal masa pandemi, pondok pesantren sementara menghentikan kegiatan pembelajaran tatap muka secara langsung dan memulangkan santri-santrinya untuk mengantisipasi klaster baru. Selama para santri di pulangkan, kegiatan pengajaran dan mengaji tetap berlangsung di rumah masing-masing atau dilakukan secara daring, namun pembelajaran daring membuat para musyrifah tidak dapat mendampingi dan mengawasi para santri secara langsung dan dengan adanya pembelajaran daring visi dan misi pondok pesantren tidak terwujud sesuai dengan harapan. Hal tersebut berjalan hingga pemerintah mengumumkan era kenormalan atau disebut newnormal dipertengahan tahun 2020.

Visi pondok pesantren pada umumnya sebagai pusat pendidikan keagamaan islam yang melahirkan santri yang mengusai ilmu agama dan ilmu-ilmu lainnya sesuai ciri khas masing-masing pesantren, beriman, bertakwa, dan berakhlak mulia, serta menjunjung tinggi nilai-nilai luhuh bangsa. Misi pondok pesantren pada umumnya adalah melaksanakana pendidikan keagamaan sesaui ciri khas masing-masing pondok pesantren, membiasakan santri untuk beribadah wajib maupun sunah, membiasakan membaca al-Qur'an,dzikir, dan mengkaji kitab-kitab keagamaan klasik di bawah bimbingan ustadz, ustadzah atau pengasuh pesantren. Di pondok pesantren tidak hanya transformasi pengetahuan saja, namun apa yang sudah mereka pelajari di internalisasi dalam kegiatan sehari-hari santri di pondok pesantren. Maka pola pembelajaran tersebut disebut sebagai pembelajaran 24 jam. Seluruh aktivitas yang dilakukan santri di pondok pesantren adalah pembelajaran(Fahham, 2020).

Pada Juli 2020, beberapa pondok pesantren mulai menerapkan pembelajaran tatap muka, termasuk Pondok Pesantren Taruna Al-Qur'an Putri Yogyakarta. Diberlakukannya kembali pembelajaran tatap muka di pondok pesantren tertentu tidak terlepas dengan penerapan protokol kesehatan yang ketat. Ketentuan penyelenggaraan langsung ditulis dalam panduan penyelenggaraan pembelajaran keputusan bersama 4 Menteri Pendidikan dan kebudayaan, menteri kesehatan, dan menteri dalam negeri. Pesantren termasuk penyelenggara pendidikan yang sangat potensial terjadinya penularan covid-19. Oleh sebab itu, pemerintah sangat berhati-hati untuk mengeluarkan kebijakan terkait dengan kegiatan belajar bagi anak usia sekolah khusus pesantren (Dan et al., 2020). Terkait panduan pemberdayaan masyarakat pesantren dalam pencegahan dan pengendalian Corona virus 2019 atau dikenal (covid-19) di pondok pesantren menjadi pedoman dalam penyelenggaraan pendidikan dipesantren dalam masa pandemi.

Sebelumnya sudah ada penelitian yang serupa dengan penelitian yang kami teliti. Penelitian tersebut dilakukan oleh Dian Uswatun H, Ahmad Alfi, dan Dwi Kurniasih (Hasanah et al., 2021) dengan judul Kebijakan Pendidikan di Pondok Pesantren Al Muayyad Surakarta Selama Masa Pandemi Covid-19. Perbedaan pada penelitian tersebut dengan penelitian ini terletak pada obyek yang diteliti, penelitian tersebut berlokasi di Surakarta, sedangkan penelitian ini berlokasi di D.I.Yogyakarta.

Ada pula penelitian yang dilakuakan oleh Nur Hayati yang berjudul Pembelajaran Jarak Jauh Selama Pandemi di Pondok Pesantren Darunajah 2 Bogor. Perbedaan penelitian tersebut dengan penelitian ini yaitu penelitian yang dilakukan Nur Hayati menganalisis mengenai pembelajaran jarak jauh di masa pandemi, dari mulai kegiatan selama pembelajaran jarak jauh hingga tantangan selama pembelajaran jarak jaug 
2030 Implementasi Kebijakan Pembelajaran Tatap Muka di Pesantren Taruna Al Qur'an Putri Yogyakarta Masa Darurat Covid-19-Rafi'ul Akmal Athaillah, Fatimah Nur Rahma, M. Syahrul Qhodi Alam, Burhanudin Ahmad Fauzi, Fransisca Wulandari, Imam Safii

DOI: https://doi.org/10.31004/edukatif.v3i4.1112

berlangsung(Hayati, 2020). Sedangkan pada penelitian ini menganalisis kebijakan pembelajaran tatap muka di pondok pesantren selama masa pandemi.

Beberapa penelitian telah melakukan analisis terkait pembelajaran di pondok pesantren selama masa pandemi covid-19,namun penelitian mengenai pembelajaran pada masa pandemi masih tergolong sedikit terutama di Yogyakarta. Alasan peneliti memilihi Pondok Pesantren Taruna Al-Qur'an untuk penelitian yaitu pondok pesantren tersebut termasuk pondok pesantren yang berada di tempat padat penduduk dan memberanikan untuk melakukan pembelajaran tatap muka di tangah pandemi dan tujuan penelitian ini untuk mengetahui kebijakan-kebijakan pendidikan pada pembelajaran tatap muka di Pondok Pesantren Taruna AlQur'an Putri di Yogyakarta selama pandemi covid-19.

\section{METODE PENELITIAN}

Jenis penelitian yang digunakan merupakan jenis penelitian kualitatif bersifat deskriptif. Peneliti mendeskripsikan suatu objek, fenomena, atau setting sosial yang akan dilaporkan dalam tulisan yang bersifat naratif. Data dan fakta yang telah dikumpulkan tersebut berupa gambar dan kata daripada angka. Dalam penulisannya, laporan hasil yang di dapat berisi kutipan-kutipan fakta yang telah diungkap di lapangan untuk memberikan penguatan atas apa yang telah disajikan pada laporan (Anggito \& Setiawan, 2018).

Penelitian ini dilaksanakan di Pondok Pesantren Taruna Al-Qur'an Putri pada tanggal 25 Juni 2021. Pondok pesantren ini berlokasi di Jl. Lempongsari 4a Sariharjo Ngaglik Sleman D.I.Yogyakarta.Teknik pengumpulan data dilakukan dengan menggunakan teknik triangulasi. Menurut Wiersma tranggulasi adalah suatu cara mendapatkan data yang benar-banar dengan menggunakan pendekatan metode ganda (Bachri, 2010). Tujuan penelti memilih teknik ini adalah mengetahui keabsahan hasil data dilapangan dan mendapatkan informasi yang menyeluruh tentang perspektif penelitian. Teknik ini dilakukan dengan menggabungkan teknik wawancara dan observasi. Dalam Kamus Besar Bahasa Indonesia pengertian wawancara yaitu tanya jawab dengan seseorang yang diperlukan untuk dimintai keterangan atau pendapatnya mengenai suatu hal. Atau dengan kata lain dapat juga disebut bahwa wawancara adalah tanya jawab antara pewawancara dengan yang diwawancarai untuk meminta keterangan atau pendapat tentang suat hal (Barata, 2003). Observasi merupakan kegiatan memperhatikan fenomea secara akurat, mencatat fenomena yang muncul dan mempertimbangkan hubungan antar aspek dalam fenomena tersebut (Ni'matuzahroh; Prasetyaningrum, 2018). Observasi dilakukan untuk memantau proses pembelajaran di masa pandemic covid19 (Helaludin, 2019).

Adapun tahapan penelitian ini yaitu pertama peneliti melakukan perencanaan penelitian dan membuat instrumen wawancara, kedua peneliti menganalisis kebijakan pembelajaran tatap muka dan melakukan wawancara, dan yang terakhir peneliti menganalisis hasil temuan dan mangambil kesimpulan. Informan yang kami gunakan untuk wawancara yaitu musyrifah Pondok Pesantren Taruna Al-Qur'an yang berinisial Q dan S. Peneliti menggunakan penelitian ini karena lokasi yang mudah di jangkau, serta memudahkan peneliti untuk memperoleh data-data yang dibutuhkan untuk menjawab permasalahan yang penelit ajukan.

\section{HASIL DAN PEMBAHASAN PENELITIAN}

Pondok Pesantren Taruna Al Qur'an adalah salah satu pondok pesantren yang terletak di kota Yogyakarta yang sudah melakukan kegiatan pembelajaran tatap muka pada akhir bulan Juli 2020. Pondok pesantren ini disahkan notaris pada tanggal 21 September 2008 dan berlokasi di jalan lempongsari 4A Sariharjo, Kecamatan Ngaglik Kabupaten Sleman Provinsi Daerah Istimewa Yogyakarta. Dengan letak geografis yang sangat stategis, menjadikan pondok pesantren ini berkembang dengan sangat cepat. Program 
2031 Implementasi Kebijakan Pembelajaran Tatap Muka di Pesantren Taruna Al Qur'an Putri Yogyakarta Masa Darurat Covid-19-Rafi'ul Akmal Athaillah, Fatimah Nur Rahma, M. Syahrul Qhodi Alam, Burhanudin Ahmad Fauzi, Fransisca Wulandari, Imam Safii

DOI: https://doi.org/10.31004/edukatif.v3i4.1112

unggulan pondok pesantren ini yaitu tahfizhul Qur'an, hafal 30 juz merupakan syarat kelulusan dari Pondok Pesantren Taruna Al-Qur'an. Selain menghafal Al-Qur'an dan belajar agama, pondok pesantren ini juga terdapat pembelajaran umum seperti halnya sekolah-sekolah pada umumnya.

\section{Kebijakan Pemerintah tentang Pembelajaran di Pondok Pesantren Era Pandemi Covid-19}

Kebijakan merupakan aturan tertulis yang bersifat mengikat, yang mengatur perilaku orang dengan tujuan menciptakan tata nilai atau aturan baru untuk masyarakat yang dikeluarkan suatu organisasi atau lembaga. Berbeda dengan hukum (law) dan peraturan (regulation), kebijakan memiliki sifat adaftif dan interpratatif, walaupun kebijakan sendiri juga mengatur apa yang boleh dan tidak diperbolehkan (Dr. Arwildayanto et al., 2018). Banyaknya keragaman pemahaman dan makna tentang kebijakan, apalagi adanya perbedaan asal kata kebijakan di tiap-tiap Negara, dan juga banyaknya implikasi pada artikulasi dan konsep yang bervariasi. Kebijakan pendidikan sendiri termasuk dalam kebijakan publik, yaitu kebijakan yang urusannya menjadi urusan semua pihak (public), kebijakan yang berdampak pada masyarakat luas dan juga implementasi kebijakan pendidikan sendiri memerlukan dana yang sangat besar yang bahkan alokasi dananya diambil dari Anggaran Pendapatan dan Belanja Negara. Kebijakan pendidikan merupakan rangkaian kegiatan dan hasil perumusan langkah strategis yang dijabarkan dari visi, misi pendidikan dalam rangkai tercapainya tujuan pendidikan dalam suatu masyarakat dengan waktu yang ditentukan (Sidiq \& Widyawati, 2019).

Sesuai dengan SKB (surat keputusan bersama) empat menteri, Menteri pendidikan dan Kebudayaan, Menteri Agama, Menteri Kesehatan dan Menteri dalam Negeri Republik Indonesia tentang penyelenggaraan pembelajaran tahun ajaran 2020/2021 di masa pandemi covid-19, penyelenggaran pembelajaran tatap muka di pesantren bisa di mulai pada bulan Syawal tahun 1441 Hijriah dengan melaksanakakan prosedur protokol kesehatan(Green, 2020). Berikut adalah ketentuan yang harus dilaksanakan bagi Pondok Pesantren yang melakukan pembelajaran tatap muka: 1) Membetuk gugus tugas percepatan penanganan virus covid-19, 2) Memiliki fasilitas yang memenuhi protokol kesehatan, 3) Terbebas dari virus covid-19, dengan membuktikan oleh surat keterangan yang berasal dari gugus tugas percepatan penanganan covid-19 atau pemerintah daerah setempat, dan 4)Pimpinan, pengelola, pendidik, dan santri dalam kondisi sehat yang dibuktikan dengan surat keterangan sehat dari fasilitas pelayanan kesehatan setempat(Hadi, 2020).

Adapun protokol kesehatan yang harus dipatuhi oleh seluruh warga pondok pesantren yang telah kembali ke pondok pesantren untuk melakukan aktivitas di pondok pesantren yaitu: (1) membersihkan ruangan dan lingkungan secara berkala dengan desinfektan, (2) menyediakan sarana cuci tangan atau pemberish tangan (hand sanitizer) menggunakan sabun dan air mengalir di kamar mandi, kelas, ruang pengajar, pintu gerbang, setiap ruang tidur, ruang makan, dan tempat lain yang sering di akses, (3) memasang pesan kesahatan cara cuci tangan yang benar, cara mencegah penularan Covid-19, etika batuk dab bersin serta cara menggunakan masker yang benar, (4) membiasakan menggunakan masker, jaga jarak, mencuci tangan dengan sabun, dan menerapkan etika bersin atau batuk (Fahham, 2020).

\section{Hasil wawancara kepada musyrifah Pondok Pesantren Taruna Al-Qur’an Putri}

Peneliti melakukan wawancara dengan musyrifah pondok yang berinisial Q dan $\mathrm{S}$ terkait pembelajaran tatap muka di Pondok Pesantren Taruna Al-Qur'an di masa pandemi. Dalam wawancara tersebut terbagi menjadi beberapa pembahasan yaitu alasan Pondok Pesantren Taruna Al-Qur'an Putri memberlakukan pembelajaran tatap muka pada masa pendemi, implimentasi pembelajaran tatap muka selama masa pandemi berlangsung, peraturan terhadap kebijakan pembelajaran tatap muka di pondok pesantren, dan penerapan protokol kesehatan di pondok pesantren.

Berdasarkan hasil wawancara yang dilakukan peneliti, peneliti memperoleh hasil bahwa selama Pembelajaran Jarak Jauh, Pondok Pesantren Taruna Al-Qur'an Putri memiliki beberapa kendala, diantaranya: 
2032 Implementasi Kebijakan Pembelajaran Tatap Muka di Pesantren Taruna Al Qur'an Putri Yogyakarta Masa Darurat Covid-19-Rafi'ul Akmal Athaillah, Fatimah Nur Rahma, M. Syahrul Qhodi Alam, Burhanudin Ahmad Fauzi, Fransisca Wulandari, Imam Safii

DOI: https://doi.org/10.31004/edukatif.v3i4.1112

santriwati tidak dapat setor hafalan secara langsung, sehingga ketika terkendala dalam jaringan, maka kegiatan setoran hafalan secara daring tidak efektif dan membuat santriwati tersebut tidak dapat menyelesaikan target hafalan dengan baik. Oleh sebab itu dengan pertimbangan yang matang dan mengikuti aturan pemerintah terkait protokol kesehatan, Pondok Pesantren Taruna Al Qur'an Putri memutuskan untuk melakukan kegiatan pembelajaran tatap muka kembali dengan membuat peraturan-peraturan tambahan dengan menerapkan protokol Kesehatan sesuai dengan kebijakan pemerintah bagi pondok pesantren yang akan melakukan pembelajaran tatap muka.

Terjadinya pandemi di Indonesia pada awal maret 2020, Pondok Pesantren Taruna Al Qur'an Putri juga mengikuti kebijakan yang dikeluarkan oleh Kementrian Pendidikan dan Kebudayaan sesuai dengan edaran Nomor 15 tahun 2020 tentang pedoman penyelenggaraan belajar dari rumah (BDR) dalam masa darurat penyebaran Corona Virus Desease (Covid-19). Penyelengaraan BDR tersebut berjarak satu bulan dengan libur lebaran yang selalu dilakukan Pondok Pesantren Taruna Al Qur'an Putri setiap tahunnya, walaupun biasanya hanya selama tiga minggu saja. Pada tahun ini, dengan diselenggarakannya BDR dan liburan lebaran maka lama santriwati berada dirumah yaitu kurang lebih tiga bulan, hal ini guna menekan penyebaran virus corona. Walaupun dengan adanya BDR dan libur lebaran selama tiga bulan, santri Pondok Pesantren Taruna Al Qur'an Putri tetap melakukan kegiatan belajar mengajar menggunakan metode Pembelajaran Jarak Jauh (PJJ), agar santriwati dapat menggunakan waktu selama di rumah dengan sebaik-baiknya. Dalam pembelajaran jarak jauh, para ustadzah dan musyrifah diharuskan memanfaatkan teknologi sebaik mungkin guna melaksanakan pembelajaran online agar pembelajaran yang dilakukan bisa berjalan dengan baik dan para santriwati bisa memahami materi yang diberikan. Berbagai media aplikasi pembelajaran seperti whatsapp, google meet, google classroom juga zoom dan ditunjang dengan metode pembelajaran yang mendukung dalam proses kegiatan belajar mengajar dan kegiatan hafalan al Qur'an, sehingga para ustadzah dan musyrifah dengan mudah memberikan materi ajar.

Pada Akhir Juli 2020, dengan pertimbangan yang matang dan mengikuti aturan pemerintah terkait protokol kesehatan, Pondok Pesantren Taruna Al Qur'an Putri telah siap melaksanakan kegiatan pembelajaran tatap muka kembali dengan membuat peraturan-peraturan tambahan dengan menerapkan protokol kesehatan. Pondok Pesantren Taruna Al Qur'an Putri juga telah membentuk tim satuan tugas dalam menangani covid-19. Sebelum kembali ke pondok, para musyrifah wajib melakukan swab antigen maksimum 3 hari sebelum kembali ke pondok. Jika dari musyrifah hasil swabnya positif, maka kembali ke pondoknya ditunda terlebih dahulu dan melakukan isolasi mandiri di rumah masin-masing selama dua minggu. Sedangkan jika hasilnya negatif maka musyrifah dapat kembali ke pondok. Kedatangan musyrifah ke pondok 5 hari sebelum kedatangan santriwati. Para musyrifah pondok yang sehat dan dinyatakan negatif covid-19, melakukan persiapan era "New Normal" dalam rangka kembalinya santri ke pondok untuk pembelajaran tatap muka.

Sesuai dengan kebijakan empat menteri mengenai panduan penyelenggaraan pembelajaran pada tahun ajaran 2020/2021 di masa pandemi, Pondok Pesantren Taruna Al-Qur'an Putri telah menyesuaikan protokol kesehatan pada waktu kedatangan dan kegiatan pembelajaran di pondok pesantren pasca kedatangan.Berikut adalah persiapan-persiapan yang dilakukan untuk menyambut kedatangan santri antara lain: 1) Melakukan sterilisasi dan penyemprotan disenfektan diseluruh pondok. 2) Menyiapkan peralatan kesehatan yang memadahi seperti alat pelindung diri (APD), thermogun, masker, tempat cuci tangan, sabun, dan ruang isolasi, 3) Berkoordinasi dengan puskesmas dan keamanan setempat, 4) Menyiapkan klinik 24 jam, 5) Membentuk dan membagi tim pengurus kedatangan santriwati secara ketat dengan menerapkan protokol kesehatan, 6) Melakukan rekayasa pysichal distancing di berbagai tempat di pondok.

Santriwati yang akan kembali ke Pondok Pesantren Taruna Al-Qur'an Putri telah diberi kententuan. Berikut adalah ketentuan kedatangan santriwati Pondok Pesantren Taruna Al-Qur'an Putri: 1) Jadwal kedatangan santriwati kembali ke pondok pesantren sesuai dengan kelas masing-masing, 2) Jadwal waktu 
2033 Implementasi Kebijakan Pembelajaran Tatap Muka di Pesantren Taruna Al Qur'an Putri Yogyakarta Masa Darurat Covid-19-Rafi'ul Akmal Athaillah, Fatimah Nur Rahma, M. Syahrul Qhodi Alam, Burhanudin

Ahmad Fauzi, Fransisca Wulandari, Imam Safii

DOI: https://doi.org/10.31004/edukatif.v3i4.1112

kedatangan santriwati kembali ke pondok pesantren sesuai dengan domisili asal masing-masing, 3) Sebagai syarat kedatangan, santriwati wajib melakukan pemeriksaan Swab Antigen/Rapid Test Aantigen/GeNose19 yang sampelnya diambil dalam kurung waktu 3x24 jam sebelum keberangkatan dan menginformasikan hasil tersebut kepada musyrifah kelas masing-masing, 4) Santriwati dalam keadaan sehat (tidak demam, batuk, asma, dll) dan keluarga di rumah juga dalam keadaan sehat, tidak ada indikasi gejala covid-19/kasus suspek/kontak erat dengan orang yang positif covid-19, 5) Selama berada di rumah, santriwati diharuskan menyelesaikan urusan kesehatan dan lain-lainnya, 6) Santriwati wajib diantarkan langsung oleh orang tua/wali dengan kendaraan pribadi

7 ) Saat mengantarkan santriwati, orang tua/wali hanya boleh sampai di depan pintu gerbang pondok pesantren dan tidak diperkenankan turun dari kendaraan.

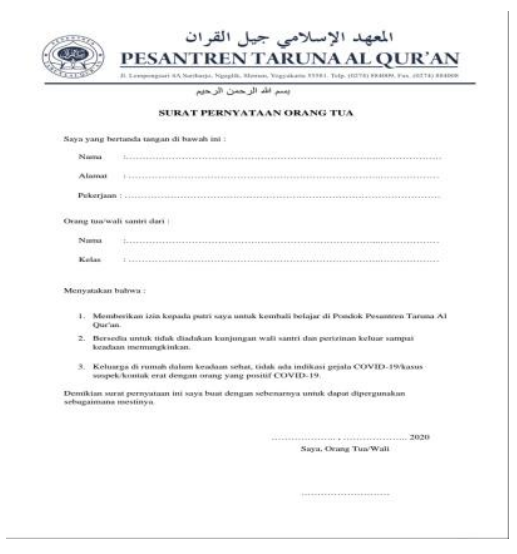

Gambar 1. Surat Pernyataan Orangtua

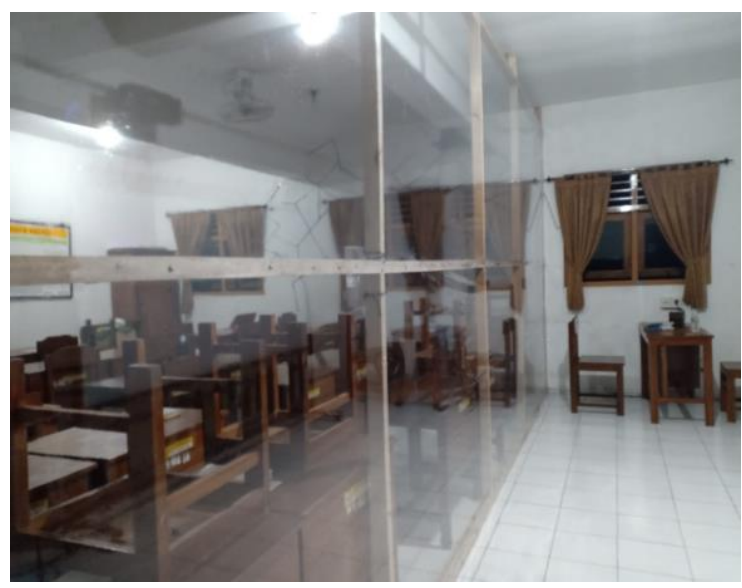

Gambar 2. Ruang Kelas yang telah didesain dengan menerapkan protokol kesehatan.

Dalam menyambut kembalinya santriwati, Tim Satgas Pondok Pesantren Taruna Al Qur'an telah membuat peraturan-peraturan sesuai dengan surat edaran Nomor : B-1673.I/DJ.I/08/2020 tentang panduan penyelenggaraan pembelajaran pada tahun ajaran 2020/2021 bagi satuan pendidikan madrasah, pesantren, pendidikan keagamaan islam, dan perguruan tinggi keagamaan islam di masa pandemi covid-19.

Protokol kesehatan tetap di terapkan dalam pondok pesantren meskipun ketika masuk santri sudah memenuhi peraturan memasuki lingkungan pondok. Selama 2 minggu setelah kedatangan santri melakukan karantina mandiri, berikut adalah tata tertib karantina Pondok Pesantren Taruna Al-Qur'an: 
2034 Implementasi Kebijakan Pembelajaran Tatap Muka di Pesantren Taruna Al Qur'an Putri Yogyakarta Masa Darurat Covid-19-Rafi'ul Akmal Athaillah, Fatimah Nur Rahma, M. Syahrul Qhodi Alam, Burhanudin Ahmad Fauzi, Fransisca Wulandari, Imam Safii

DOI: https://doi.org/10.31004/edukatif.v3i4.1112

Santriwati diwajibkan untuk: (1) tetap berada di ruang karantina, (2) menjaga suara, (3) menggunakan masker diluar maupun didalam ruangan karantina, (4) menjaga jarak, (5) menjaga kebersihan dengan membiasakan diri untuk mencuci tangan dengan sabun, (6) Makan sendiri menggunakan tempat pribadi, (7) minum menggunakan tempat minum pribadi, (8) menjaga kesehatan dengan : makan tepat waktu, minum air putih dengan cukup, minum suplemen (madu, habbatussauda, vitamin c, dll) secara rutin, (9) istirahat dengan cukup, (10) tidur maksimal pukul 21.30 WIB, (11) melapor setiap keluhan kesehatan kepada divisi kesehatan, (12) menaati seluruh tata tertib selama karantina.

Santriwati tidak diperkenankan untuk: (1) keluar dari ruang karantina tanpa keperluan, (2) berkerumun dengan santri dalam satu tempat karantina ataupun dengan ruang karantina yang berbeda, (3) bertemau ke kamar lain, (4) menemui, bercakap-cakap serta berkerumun dengan santri lain, (5) makan berjamaah, (6) minum dengan tempat minum orang lain, (7) begadang.

Implementasi kebijakan dalam konteks pendidikan adalah alur kegiatan pendidikan yang menyangkut seluruh komponen pendidikan guna mewujudkan progam-progam yang telah disepakati bersama agar menghasilkan manfaat yang baik yang dapat dirasakan oleh seluruh pelaku pendidikan (Dr. Arwildayanto et al., 2018). Walaupun pandemi covid-19 belum berakhir, sektor pendidikan harus tetap berjalan sebagaimana mestinya. Banyaknya kebiasaan-kebiasaan baru yang terjadi di era covid-19 dalam rangka memutus rantai penyebaran covid-19. Begitu juga dengan pondok pesantren Taruna Al Qur'an Putri, terkait dengan kebijakan pendidikan akibat covid-19 menyebabkan perubahan atau perilaku kebiasaan baru yang terjadi di pondok. Dampak yang terlihat dari kebijakan era new normal antara lain: 1) Para musyrifah, pengurus pondok, dan juga santriwati selalu mentaati protokol kesehatan dengan memakai masker saat beraktifitas di lingkungan pondok pesantren, menjaga jarak dan tidak berkerumun, dan selalu mencuci tangan dengan air yang mengalir, 2) Makan dan minum dengan peralatan pribadi, tidak diperkenankan makan dan minum bersama dalam satu tempat dengan santriwati lainnya, 3) Ruang tidur yang biasanya di campur dari kelas 7 sampai kelas 10, menjadi perkelas untuk mengantisispasi penyebaran virus corona, 4) Sholat fardu yang awalnya dilakukan secara berjama'ah di mushola menjadi sholat berjama'ah dengan teman sekelasnya, 5) Selama masa pandemi covid-19 berlangsung, Pondok Pesantren Taruna Al-Qur'an Putri meniadakan kunjungan walisantriwati dan tamu dari luar pondok, 6) Meniadakan kegiatan yang menimbulkan kerumunan, 7) Pemberian sekat tembus pandang antara guru atau ustadzah dengan santriwati di ruang kelas

Demi saling melindungi dan kebaikan bersama, adaptasi kebiasan baru tidak membuat santriwati putus semangat, mereka tetap semangat belajar, menghafal Al-Qur'an dan mengikuti aktivitas di Pondok Pessantren Taruna Al-Qur'an Putri.

\section{KESIMPULAN}

Saat ini pandemi covid-19 masih berlangsung, mayoritas lembaga pendidikan masih melakukan pembelajaran secara daring. Namun pembelajaran daring dirasa kurang efektif di terapkan bagi pondok pesantren, karena pondok pesantren merupakan lembaga pendidikan yang harus dilakukan secara tatap muka, tidak semua yang diajarkan di pondok pesantren bisa dilakukan dengan PJJ. Oleh karena itu Menteri pendidikan dan Kebudayaan, Menteri Agama, Menteri Kesehatan dan Menteri dalam Negeri Republik Indonesia, membuat SKB terkait pembelajaran di masa pandemi. Pondok pesantren merupakan salah satu lembaga pendidikan yang diizinkan untuk melakukan pembelajaran tatap muka dengan syarat harus menerapkan protokol kesehatan yang sesuai dengan pedoman yang telah dibuat pemerintah. Dari hasil penelitian yang kami lakukan, menunjukkan bahwa Pondok Pesantren Taruna Al-Qur'an Putri telah menerapkan protokol kesehatan yang mengacu pada kebijakan pemerintahan tentang ketentuan dan panduan penyelenggaran pembelajaran tatap muka di pondok pesantren. 
2035 Implementasi Kebijakan Pembelajaran Tatap Muka di Pesantren Taruna Al Qur'an Putri Yogyakarta Masa Darurat Covid-19-Rafi'ul Akmal Athaillah, Fatimah Nur Rahma, M. Syahrul Qhodi Alam, Burhanudin Ahmad Fauzi, Fransisca Wulandari, Imam Safii

DOI: https://doi.org/10.31004/edukatif.v3i4.1112

\section{UCAPAN TERIMA KASIH}

Kami ucapkan terimakasih kepada seluruh pihak yang telah berpartisipasi dalam pembuatan jurnal ini, terutama kepada Pondok Pesantren Taruna Al-Qur'an Putri yang telah bersedia untuk dijadikan penelitian kami.

\section{DAFTAR PUSTAKA}

Aidah, S. N. T. P. K. (2020). Kitab Sejarah Covid-19. Penerbit Kbm Indonesia.

Anggito, A., \& Setiawan, J. (2018). Metodologi Penelitian Kualitatif. Cv Jejak (Jejak Publisher).

Bachri, B. S. (2010). Meyakinkan Validitas Data Melalui Triangulasi Pada Penelitian Kualitatif. Jurnal Teknologi Pendidikan, 10(1), 46-62.

Barata, A. A. (2003). Dasar-Dasar Pelayanan Prima. Pt Elex Media Komputindo. Https://Www.Google.Co.Id/Books/Edition/Dasar_Dasar_Pelayanan_Prima/0wfqnzlfnwmc?Hl=En\&Gbp $\mathrm{v}=1 \& \mathrm{Dq}=$ Pengertian + Wawancara $\& \mathrm{Pg}=\mathrm{Pa} 117 \&$ Printsec $=$ Frontcover

Dan, P., Coronavirus, P., Rahmat, D., Yang, T., \& Esa, M. (2020). Coronavirus Disease 2019. 2019, 1-46.

Dr. Arwildayanto, M. P., Dr. Arifin Suking, M. P., \& Dr. Warni Tune Sumar, S.Pd., M. P. (2018). Analisis Kebijakan Pendidikan Kajian Teoritis, Eksploratif Dan Aplikatif. In Kebijakan Publik. (Vol. 53, Issue 9).

Fahham, A. M. (2020). Pembelajaran Di Pesantren Pada Masa Pandemi Covid-19. Kajian Singkat Terhada Isu Aktual Dan Strategis, Xii, No 14, 14. Puslit/Files/Info_Singkat/Info Singkat-Xii-14-Ii-P3di-Juli-2020190.Pdf

Hadi, A. (2020). Panduan Menjalani New Normal Di Pesantren Pada Masa Pandemi Corona. Tirti.Id. Https://Tirto.Id/Panduan-Menjalani-New-Normal-Di-Pesantren-Pada-Masa-Pandemi-Corona-Fk5g

Hasanah, D. U., Alfi, A., \& Kurniasih, D. (2021). Kebijakan Pendidikan Di Pondok Pesantren Al Muayyad Surakarta Selama Pandemi Covid-19. Jurnal Pendidikan Islam Al-Ilmi, 4(1).

Hayati, N. (2020). Pembelajaran Jarak Jauh Selama Pandemi Di Pondok Pesantren Darunajah 2 Bogor. Resiprokal: Jurnal Riset Sosiologi Progresif Aktual, 2(2), 151-159.

Helaludin, H. W. (2019). Analisis Data Kualitatif: Sebuah Tinjauan Teori Dan Praktik. Edisi Pertama, Cetakan Ke-1, Makasar.

Kemenskes. (N.D.). Kesiapsiagaan Menghadapi Infeksi Covid-19. Kementran Kesehatan Republik Indonesia. Retrieved July 3, 2021, From Https://Www.Kemkes.Go.Id/Folder/View/Full-Content/StructureFaq.Html

Ni'matuzahroh; Prasetyaningrum, S. (2018). Observasi Teori Dan Aplikasi Dalam Psikologi (Pertama). Universitas Muhammadiyah Malang.

Pengelola Web Kemendikbud. (2020). Penyesuaian Keputusan Bersama Empat Menteri Tentang Panduan Pembelajaran Di Masa Pandemi Covid-19. Kementrian Pendidikan Dan Kebudayaan. Https://Www.Kemdikbud.Go.Id/Main/Blog/2020/08/Penyesuaian-Keputusan-Bersama-Empat-MenteriTentang-Panduan-Pembelajaran-Di-Masa-Pandemi-Covid19

Qomar, M. (2005). Pesantren Dari Transformasi Metodologi Menuju Demokratisasi Institusi (S. Mahdi, Sayed; Bhawono (Ed.)). Penerbit Erlangga.

Rosyid, Moh Zaiful; Fauzi, Achmad; Mustajab; Subakti, T. H. (2020). Pesantren Dan Peneglolaannya (T. Abdillah, Kudrat; Busahwi; Handayani (Ed.)). Muta Media Publishing.

Sidiq, U., \& Widyawati, W. (2019). Kebijakan Pemerintah Terhadap Pendidikan Islam Di Indonesia. Ponorogo: Nata Karya. 
2036 Implementasi Kebijakan Pembelajaran Tatap Muka di Pesantren Taruna Al Qur'an Putri Yogyakarta Masa Darurat Covid-19-Rafi'ul Akmal Athaillah, Fatimah Nur Rahma, M. Syahrul Qhodi Alam, Burhanudin Ahmad Fauzi, Fransisca Wulandari, Imam Safii DOI: https://doi.org/10.31004/edukatif.v3i4.1112

Teoretis, K. (N.D.). Analisis Kebijakan Pendidikan.

Wasito; Wuryastuti, H. (2020). Coronavirus (J. Deviyanti (Ed.); Pertama). Lily Publisher.

Winata, K. A., Zaqiah, Q. Y., Supiana, S., \& Helmawati, H. (2021). Kebijakan Pendidikan Di Masa Pandemi. Ad-Man-Pend: Jurnal Administrasi Manajemen Pendidikan, 4(1), 1-6. 